УДК 378.147:372.8004

DOI:

Оксана Ісаєва, доктор педагогічних наук, професор кафедри педагогіки та інноваџійної освіти Національного університету “Львівська політехніка", доиент кафедри латинської та іноземних мов Львівського національного медичного університету імені Данила Галищького

\title{
ВЕКТОР РЕФОРМУВАННЯ ВИЩОЇ ОСВІТИ В УМОВАХ ГЛОБАЛІЗАЦІЇ
}

У статті розглянуто вплив глобалізації на реформування формату вищої освіти. Глобалізація освіти як мультиаспектний $і$ багаторівневий прочес, одночасно складний $і$ доволі суперечливий, поєднує методи навчання та виховання різноманітних світових освітніх систем з метою розвитку основних галузей та формування фахівия як особистості. Розглянуто вимоги, які глобалізачія висуває до підготовки працівників майбутнього, адже метою сучасної системи освіти є розвинути особистість, здатну до самореалізації $і$ навчання упродовж життя.

Глобалізація як інтеграиійний процес пошуку надсучасних форм взаємодії у сфері вищої освіти передбачає вивчення студентами основних дисциплін навчального плану за новими методиками. Володіння високим рівнем умінь і навичок, які затребувані сучасним ринком праці, також відіграють важливу роль в умовах глобалізації. Ці процеси дадуть змогу надалі модернізувати освітню галузь, сприятимуть ії входженню у міжнародне освітне товариство та уможливлять визнання украӥнських дипломів.

Ключові слова: глобалізація; вищза освіта; професійна підготовка; сучасний фахівецьь.

Puc. 1. Jim. 8.

Oksana Isayeva, Doctor of Sciences (Pedagogy), Professor of the Pedagogy and Innovative Education Department Lviv Polytechnic National University, Associate Professor of the Latin and Foreign Languages Lviv Danylo Halytskiy National Medical University

\section{THE COURSE OF REFORMING HIGHER EDUCATION IN THE CONDITIONS OF GLOBALIZATION}

The article deals with the impact of globalization on reforming the quality of higher education. Globalization's impact on education has an incredible effect on local pedagogies, assessment, and curricula. Globalization of education as a multifaceted and multileveled process, both complex and quite controversial, combines methods of teaching and training various world educational systems in order to develop major branches and form a specialist as personality. The main and determining factors of globalization are the development of science and technology, which will define the appropriate level of dynamics in education. Globalization is not only irreversible, but also a required process, as it is a definite cultural system that allows the exchange of knowledge, the formation of a single educational space. The requirements of globalization are considered for the training of future workers, as the goal of modern education system is to develop a personality capable of self-realization and lifelong learning. Personality, her emotions, motivations and development become the main lever in the process of globalization of higher education.

Higher education is outlined as a central dynamic force of modern globalization processes and a determinant of the existence of a single information space in order to form a person as a specialist. The process of globalization of vocational education is considered through the prism of the participation of educational institutions in the main directions and forms of globalization.

Globalization as an integration process of searching for state-of-the-art forms of interaction in the field of higher education involves students studying the main disciplines of the curriculum using new methods. High levels of skills and abilities, which are in demand in current labour market, also play an important role in globalization. These processes will make it possible to further modernize educational branch, promote its entry into the international educational space and enable the recognition of Ukrainian diplomas.

Keywords: globalization; higher education; professional training; modern specialist.

П остановка проблеми у загальному вигляді. Сьогодення розглядає вищу освіту як рушійний чинник соціальноекономічного, культурного та політичного життя країни. 3 цією метою укладено і винесено на громадське обговорення Проєкт “Стратегії розвитку вищої освіти в Україні на 2021-2031 роки". Його необхідність викликана завершенням дії Національної стратегії розвитку освіти в Україні у 2021 р. (Указ Президента України від 25 червня 2013 р. № 344/2013) [8] та зумовлена зростанням глобальної конкуренції й мобільності, інтеграції 
ринків і прориву у сфері інформаційних технологій. Власне аналіз інформаційного суспільства довів, що найбільшою цінністю стали не природні ресурси і не розвиток економіки, а саме знання, нові технології, рівень освіченості особистості та здатність ці знання продукувати, генерувати і вміло послуговуватися ними на практиці, оскільки: “Суспільство знань, що застосовуються у сучасному філософському та суспільствознавчому дискурсі, описує не сталий соціальний феномен, а футурологічну модель, яка може реалізуватися за наявності певних сприятливих чинників і виступити формою розв'язання протиріч попередньої інформаційної стадії розвитку людства" $[7,75]$.

Отож, глобалізація сфери вищої освіти передбачає один або поєднання кількох загальносвітових тенденцій в галузі професійної підготовки, тобто перехід до глобалізації професійної освіти повинен мати поетапний системний характер. Сутність і зміст системності професійної освіти визначається розстановкою, аналізом і прогнозуванням процесів глобалізації за принципом “від загального - до конкретного” 3 поступовим ускладненням завдань.

Актуальність пропонованої розвідки зумовлена глобальними процесами в усіх сферах діяльності суспільства, які унеможливлюються без високого рівня фахівців.

Метою дослідження $\epsilon$ визначити i схарактеризувати перспективи оновленого формату вищої освіти 3 огляду на глобалізацію професійної освіти.

Завдання окреслено відповідно до мети:

- визначити суть освітнього середовища для студентів;

- сформувати самодостатню особистість, здатну до самореалізації у кризових умовах.

Аналіз останніх досліджень і публікацій. Аналізу теоретичних основ глобалізації освіти присвячені розвідки 3. Баумана, У.Бека,І. Валлерстайна, Е. Гідденс, Р. Миненкова, Н. Покровського, П. Скотта, А. Согомонова, А. Уткіна, В. Федотової, В. Ярської; вища освіта у глобальному контексті перебуває у центрі уваги науковців Е. Барті, Т. Бреч, М. Ван дер Вейде, Г. Каллан, Г. Макбурні тощо; проблеми інтернаціоналізації вищої освіти розглядаються А. Ареф'євим, Н. Дмитрієвим, І. Зорниковою, С. Носковою, Ф. Шерегою; національну політику вищої освіти у відповідь на тенденції інтернаціоналізації в країнах Європи досліджують М. Ван дер Вейде; А. Галаган і П. Скотт проводять аналіз освітніх реформ ХХ ст. в країнах Європи; Б. Яндх'яла розглядає суть та наслідки приватизації вищої освіти в Індії, аналізуючи негативні результати цього процесу.
Виклад основного матеріалу й обгрунтування отриманих результатів дослідження. Глобальні виклики пандемії КОВІД-19, посилення впливу світового ринку праці й затребуваність освітніх послуг нового взірця з розвитком інформаційних технологій дають змогу молодому поколінню зосередити увагу на вищій освіті в оновленому форматі. Тому дослідники дискутують про тенденцію аксіологізації освіти. Власне, науковці А. Кирякова й Т. Ольховська розглядають аксіологізацію як процес, результатом якого виступає розвиток ціннісного ставлення студента до пізнання, професії, себе й інших у стійкі професійно значущі й життєві ціннісні орієнтації, що зумовлюють пошук, оцінку, вибір і проєкцію свого життєвого шляху $[5,125]$. Тобто, вища освіта розглядається як центральна рушійна сила сучасних глобалізаційних процесів і детермінанта щодо існування єдиного інформаційного простору 3 метою формування особистості як фахівця в освітньому просторі.

Однак не варто забувати і про розвиток та становлення особистості в освітньому середовищі, адже метою сучасної системи освіти $\epsilon$ завдання розвинути особистість, здатну до самореалізації [1], тобто формування оновленої стратегії особистісного і професійного зростання студентів; уповноваження студентів відповідальністю і вмінням відповідати за власні вчинки; делегування адаптації щодо професійного виконання обов'язків майбутніми фахівцями; налаштування студентів щодо прийняття самостійних рішень та визначення шляхів їх реалізації.

Погоджуємося $з$ твердженням науковця, що основним засобом реалізації соціальноособистісного типу освіти є використання педагогічних технологій проблемного, диференційованого, рефлексивного, діалогового навчання й виховання, а також технологій колективної творчої діяльності тощо. Кожна з тих технологій здійснює внесок у розвиток особистості студента, у його соціалізацію [6] в освітньому середовищі вишу.

Увагу також варто зосередити на тому, що успішний фахівець повинен розв'язувати проблеми креативно, швидко набувати нових навичок і не відчувати себе пригніченим, коли перед ним постають нові виклики; бути відкритим до колег і легко пристосовуватися до перемінливих умов; мати здатність адаптувати набуту інформацію до нових ситуацій; вміти оцінити стратегії і тактики, тобто думати, діяти та приймати рішення. Особливу увагу варто приділяти формуванню цінностей та впевненості у собі, профорієнтації, рефлексії чи почутті усвідомленості кожного 
вчинку, тобто формувати особистісну i професійну культуру майбутніх спеціалістів. Отож, основні навички, якими повинен володіти майбутній фахівець в умовах глобалізації:

- когнітивна гнучкість як життєва позиція;

- когнітивна адаптація у діяльності;

- емоційний інтелект;

- креативність, критичність, логічність думки та чутливість до проблем;

- критичне й аналітичне мислення;

- ініціативність і саморегуляція;

- ІКТ-грамотність;

- співпраця в команді та комунікація.

Проте, упродовж останніх років скорочення затрат на вищу освіту, які спостерігаються в Україні, засвідчує, що ця галузь не $\epsilon$ пріоритетною для держави. Відповідно значна кількість абітурієнтів вступають у закордонні виші, оскільки існує невідповідність між структурою підготовки кадрів і потребами ринку праці, що вдало підтверджує науковець і практик: "Подібна ситуація зумовлюється зростанням кількості навчальних закладів з низьким рівнем викладання, рівно як і тим фактом, що значна частка молодих людей вчаться погано або взагалі не вчаться, що дозволяє давати їм на виході жорстку і вкрай неприємну, але загалом об'єктивну оцінку: випускник злегка навчений, трохи вихований, творчо не розвинений” $[2,8]$.

Також фігурує прірва між низьким рівнем взаємодії освітніх та наукових закладів у здійсненні навчальної, наукової та інноваційної діяльності університетів, тобто кваліфікаційні вимоги не відповідають галузевим стандартам і потребам сучасності. Отож, консерватизм вишів не завжди доречний при формуванні освітніх програм чи силабусів, позаяк трапляється розбіжність 3 міжнародними нормами. Адже “Оновлення змісту навчальних дисциплін та науковометодичного забезпечення освітнього процесу також відіграє важливу роль у процесі фундаменталізації професійної освіти” [3, 37], яка тісно пов'язана з процесами глобалізації.

Уважаємо, що глобалізація освіти - це мультиаспектний і багаторівневий процес, одночасно складний і доволі суперечливий, який поєднує методи навчання та виховання різноманітних світових освітніх систем з метою розвитку основних галузей і формування фахівця як особистості, що відображено на рисунку 1.

Тому варто зауважити, що реформована вища освіта повинна зосереджувати увагу на:

- розвитку міжнародної інтеграції та гуманізації вищої школи;

- формуванні основ навчання та вдосконалення

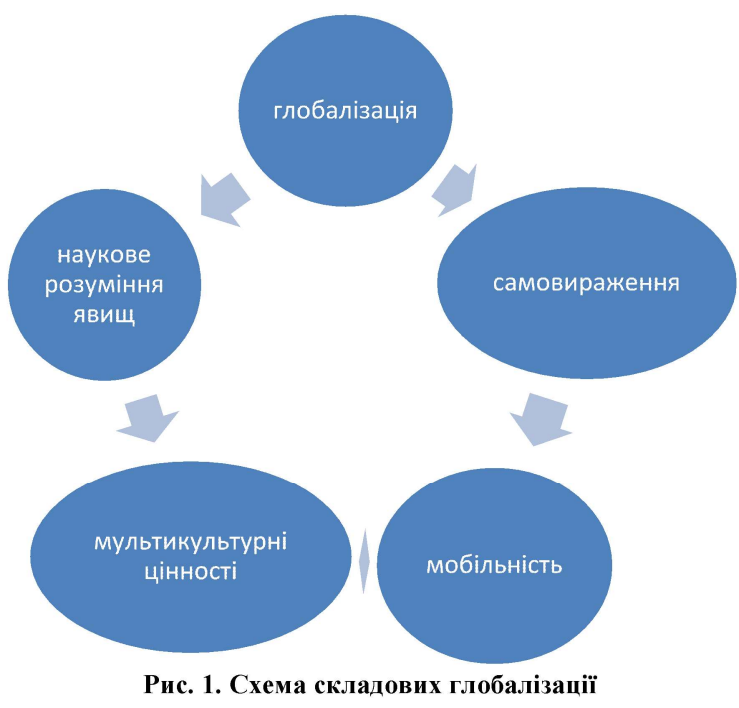

у професійній діяльності упродовж життя; - інформатизації освітньої галузі незалежно від iï рівня;

- зосередженні на фундаменталізації, яка передбачає оновлення підходу до якості освіти;

- орієнтації на глобалізацію, яка передбачає академічну мобільність як студентів, так і викладачів та спільні навчальні програми;

- розширенні можливостей академічної і дослідницької креативності у студентів;

- публікації наукових результатів у провідних індексованих зарубіжних журналах.

Зазначимо, що повноцінну якісну освіту неможливо здобути без науково-дослідницької діяльності як основи формування у студентів гнучкого і самостійного творчого мислення, навичок самонавчання, мотивації до постійного професійного удосконалення, розвитку здібностей сприймати чи самостійно створювати нові ідеї й продукувати їх у практику. Тобто наука і освіта $\epsilon$ взаємопов'язаними сферами духовної культури, які формують світогляд, етичні і моральні цінності тощо. Як влучно зауважує дослідниця І. Карнаухова [4], пошуково-дослідницька діяльність як засіб професійної підготовки уможливлює творче застосування навчального матеріалу на практиці та плавний перехід від навчально-пізнавальної до самостійної творчої професійної діяльності, що забезпечується реалізацією компетентнісного підходу в підготовці фахівця. Тобто взаємодія освіти 3 наукою сприяє здобуттю студентом високого рівня наукових, професійних і загальних компетентностей, необхідних для майбутньої кар'єри в умовах глобалізаційних процесів.

Загальновідомо, що сенс навчання змінюється в умовах глобалізації і, таким чином, відбувається переорієнтація освітньої політики загалом. Процес глобалізації професійної освіти розглядається крізь 
призму участі закладів освіти в основних напрямах і формах глобалізації: інтернаціоналізації, інтеграції, координації, кооперації та уніфікації в сфері професійної освіти. Саме тому університети також повинні бути задіяні в усіх видах діяльності одночасно, а саме глобально і національно; розробляти нові комбінаторні моделі і стратегії, змінювати внутрішню культуру чи навчальне середовище й оновлювати зовнішню місію. Обізнаність, цікавість, адаптивність та комунікативність - це основні характеристики успішної реалізації спеціаліста оновленого формату в умовах глобалізації.

Висновки. Реформування вищої освіти в умовах глобалізації має шанс знову здобути статус високого престижу і авторитету та значущості для суспільства, оновивши мету і завдання вишів, запровадивши ІКТ-технології та змінивши формат організації освітнього процесу. Особистість, їі емоції, мотивації і розвиток стають головним важелем у процесі глобалізації вищої освіти. Володіння високим рівнем умінь і навичок, які затребувані сучасним ринком праці в умовах глобалізації, а саме гнучкість мислення, формування власної думки та впевненість у прийнятті рішень, взаємодія з партнерами, вміння управляти персоналом, комплексне багаторівневе розв'язання проблем вважаються актуальними для сучасного фахівця, тобто сенс навчання змінюється в умовах глобалізації. Адже глобалізація університетів - це специфічний інтеграційний процес пошуку надсучасних форм взаємодії у сфері вищої освіти, що передбачає вивчення студентами основних дисциплін навчального плану, знання яких дасть змогу в подальшому модернізувати освітню галузь і сприятиме її входженню у міжнародне освітне товариство та визнанню українських дипломів.

Перспективу подальших досліджень вбачаємо в аналізі базових компетенцій випускників вишів в умовах КОВІД-19 пандемії.

\section{ЛIТЕРАТУРА}

1. Балл Г. О. Сучасний гуманізм і освіта: соціальнофілософські та психолого-педагогічні аспекти. 2003. 128 с.

2. Горшков М. К. Образование и общество в социологическом измерении (вместо предисловия). Россия реформирующаяся: ежегодник. Вып. 8. 2009. $464 \mathrm{c}$.

3. Ісаєва О., Кушка Б. Фундаменталізація як важлива складова вищої технічної освіти._Молодь і ринок. № 4 (190). 2021. C. 35-39. DOI: https://doi.org/10.24919/2617$\underline{0825.4 / 190.2021}$

4. Карнаухова И. Б. Поисково-исследовательская деятельность как средство развития творческой самостоятельности студентов в процессе профессиональной подготовки: дисс... канд. пед. н.: спец. $13.00 .08 .2000 .158 \mathrm{c}$.

5. Кирьякова А. В., Ольховая Т. А. Реализация аксиологического подхода в университетском образовании. Высшее образование в России. №5. 2010. C. $124-128$.

6. Селевко Г. К. Современные образовательные технологии : Учебное пособие. (1998). 256 с.

7. Чайка І.Ю. “Суспільство знань”: футурологічний проект чи нова соціальнареальність? Культурологічнийвісник Нижнььої Наддніпрянщчини. № 29. 2012. С. 71-75.

8. Стратегія розвитку вищої освіти в Україні на 2021 -2031 роки. URL: http://reform.org.ua.

\section{REFERENCES}

1. Ball, H. O. (2003). Suchasnyy humanizm i osvita: sotsialno-filosofski ta psykholoho-pedahohichni aspekty [Modern humanism and education: socio-philosophical and psychological-pedagogical aspects]. 128 p. [in Ukrainian].

2. Gorshkov, M. K. (2009). Obrazovaniye i obshchestvo $\mathrm{v}$ sotsiologicheskom izmerenii (vmesto predisloviya) [Education and society in the sociological dimension (instead of the preface)]. Reforming Russia. Vol. 8. 464 p. [in Russian].

3. Isayeva, O. \& Kushka, B. (2021). Fundamentalizatsiyayak vazhlyva skladova vyshchoyi tekhnichnoyi osvity [Fundamentalization as an important component of higher technical education]. Youth and market. No. 4 (190). pp. 35-39. DOI: https://doi.org/10.24919/2617-0825.4/ 190.2021 [in Ukrainian].

4. Karnaukhova, I. B. (2000). Poiskovo-issledovatelskaya deyatelnost kak sredstvo razvitiya tvorcheskoy samostoyatelnosti studentov $\mathrm{v}$ protsesse professionalnoy podgotovki [Search and research activity as a means of developing students' creative independence in the process of professional training]. Candidate's thesis. 158 p. [in Russian].

5. Kiryakova, A. V. \& Olkhovaya, T. A. (2010). Realizatsiya aksiologicheskogo podkhoda $\mathrm{v}$ universitetskom obrazovanii [Implementation of the axiological approach in university education]. Higher education in Russia. No. 5. pp. 124-128. [in Russian].

6. Selevko, G. K. (1998). Sovremennyye obrazovatelnyye tekhnologii : uchebnoye posobiye [Modern educational technologies]. Textbook. 256 p. [in Russian].

7. Chayka, I.Yu. (2012). "Suspilstvo znan": futurolohichnyy proekt chy nova sotsialna realnist? ["Knowledge Society": a futurological project or a new social reality?] Cultural Bulletin of the Lower Dnieper Region. No. 29. pp. 71-75. [in Ukrainian].

8. Stratehiya rozvytku vyshchoyi osvity v Ukrayini na 2021 - 2031 roky [Strategy for the development of higher education in Ukraine for 2021 - 2031]. Available at: http:// reform.org.ua. [in Ukrainian].

Стаття надійшла до редакції 11.08.2021 